Int. J. Dev. Biol. 60: 29-38 (2016)

doi: $10.1387 / \mathrm{ijdb} .150132 \mathrm{rh}$

\title{
SDF-1 controls the muscle and blood vessel formation of the somite
}

\author{
AISHA ABDUELMULA ${ }^{1,}$ RUIJIN HUANG ${ }^{2,3,}$ QIN PU1, HIROKAZU TAMAMURA ${ }^{4}$, GABRIELA MOROSAN-PUOPOLO ${ }^{1}$ \\ and BEATE BRAND-SABERI*,1 \\ 'Institute of Anatomy, Department of Anatomy and Molecular Embryology, Ruhr-University Bochum, Bochum, \\ Germany, ${ }^{2}$ Institute of Anatomy, Department of Neuroanatomy, Medical Faculty Bonn, Rheinische Friedrich- \\ Wilhelms-University of Bonn, Bonn, Germany, ${ }^{3}$ Department of Molecular Embryology, Institute of Anatomy and Cell \\ Biology, Albert-Ludwig-University of Freiburg, Freiburg, Germany and ${ }^{4}$ Institute of Biomaterials and Bioengineering, \\ Tokyo Medical and Dental University, Department of Medicinal Chemistry, Chiyoda-ku, Tokyo, Japan
}

\begin{abstract}
Stromal-cell-derived factor-1 (SDF-1), the only ligand of the chemokine receptor CXCR4, is involved in skeletal muscle development. However, its role in the proliferation, differentiation and migration of somite cells is not well understood. Here, we investigated its function during somite development in chicken embryos by using gain-of-function and loss-of-function experiments. Overexpression of SDF-1 was performed by electroporating SDF-1 constructs into the ventrolateral part of the somite, or by injecting SDF-1-expressing cells into the somites of stages HH14-16 chicken embryos. We found that enhanced SDF-1 signaling induced cell proliferation in the somite. This resulted in an increase in number of both myotomal and endothelial cells. In contrast, inhibition of SDF-1/CXCR4 signaling led to a reduction of myotomal cells. Injection of SDF-1 producing cells into the somite induced ectopic localization of myotomal cells in the sclerotome. Although many SDF-1-expressing somite cells colonized the limb, only a few of them developed into muscle cells. This resulted in a reduction of the limb muscle mass. This means that most myogenic progenitors were stopped on their migration towards the limb due to the high concentration of the SDF-1 signal in the somite. Most of the SDF-1-expressing somite cells found in the limb were of endothelial cell fate and they contributed to the increase in limb blood vessels. These results reveal that SDF-1 promotes the proliferation of both myogenic and angiogenic progenitor cells of the somite and controls myotome formation. Furthermore, SDF-1 controls muscle and blood vessel formation in the limb in different ways.
\end{abstract}

KEY WORDS: chicken embryo, SDF-1, CXCR4, proliferation, myogenesis, angiogenesis

\section{Introduction}

Stromal-cell-derived factor-1 (SDF-1) is the only ligand of the chemokine receptor CXC-motive-chemokine receptor 4 (CXCR4). The SDF-1/CXCR4 axis has been reported to provide cells with directional cues as well as to control the proliferation, differentiation and survival of many cell types including human and murine hematopoietic stem and progenitor cells (Lapidot and Kollet. 2002; Hodohara et al., 2000; Lataillade et al., 2000; Bleul et al., 1998; Wang et al., 1998; Aiuti et al., 199). SDF-1 is the main chemokine which plays a role in the migration of hematopoietic stem cells (HSCs) and endothelial progenitor cells (Ceradini et al., 2004; Hattori et al., 2003; Wright et al., 2002). SDF-1 is a chemotactic factor for human hematopoietic CD34+ progenitor cells and has an important role in the homing of these cells to the bone marrow (Möhle et al., 1998; Aiuti et al., 1997; Dutt et al., 1998). Additionally, platelet-derived SDF-1 enhances differentiation of CD34+ cells into endothelial progenitor cells (Stellos et al., 2008). In different injured tissues, SDF-1 has been shown to be up-regulated and is thought to control repair by recruiting stem/progenitor cells to the place of injury (Hatch et al., 2002). Butler and his group showed that SDF-1 levels are increased in diabetics with proliferative diabetic retinopathy, and that SDF-1 probably has an important role in the migration of HSC-derived endothelial progenitor cells to the location

Abbreviations used in this paper: SDF-1, stromal-cell-derived factor-1.

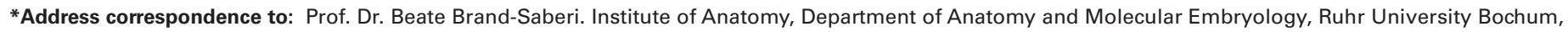
44780 Bochum, Germany. Tel.: +49(0)234/32-27780. Fax: +49(0)234/32-14474. E-mail: beate.brand-saberi@rub.de
}

Accepted: 5 November 2015.

ISSN: Online 1696-3547, Print 0214-6282 


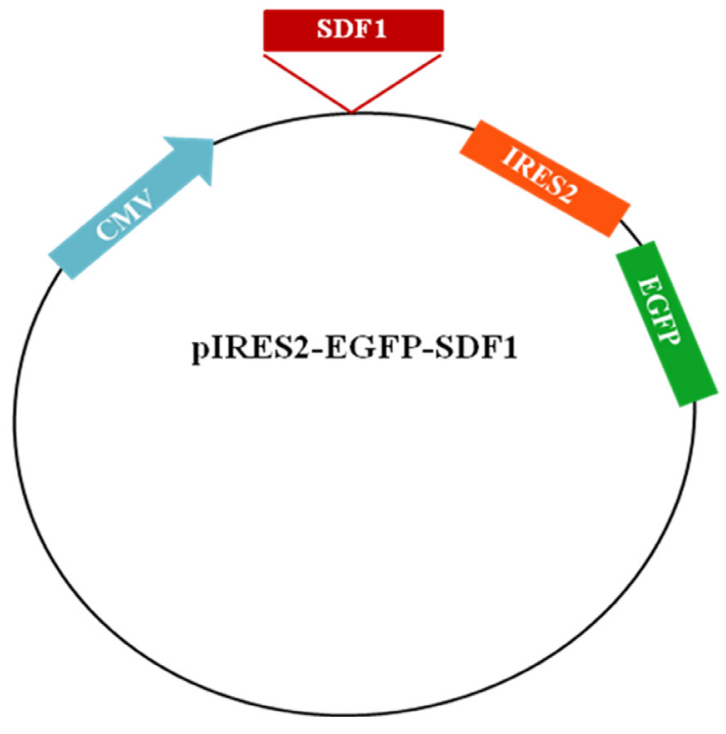

Fig. 1. The pIRES2-EGFP-SDF-1 construct. The SDF-1 coding sequence was inserted into the pIRES2-EGFP vector (Clontech).

of vascular wounds by regulating molecules in the wound-repair response. Furthermore, they demonstrated that SDF-1 is involved in proliferative retinopathy and is thought to be an ideal target for the elimination of proliferative retinopathy (Butler et al., 2005).

Recent studies have shown that SDF-1/CXCR4 plays a pivotal role in skeletal muscle development (Vasyutina et al., 2005; Yusuf et al., 2006; Rehimi et al., 2008). Premyogenic precursor cells migrate from the somites into the limb bud mesenchyme, where they start to express CXCR4 and generate muscles of the appropriate size (Vasyutina et al., 2005). CXCR4 mutant mice showed acute defects of limb myogenesis, as demonstrated by a reduction of limb musculature (Odemis et al., 2005). During the cloaca muscle formation, SDF-1 is required for the migration of myogenic precursor cells from the hind limb into the cloaca (Rehimi et al., 2008). SDF-1 plays the same role for the migration of myogenic precursor cells from the forelimb to the trunk during the formation of the shoulder girdle muscles (Masyuk et al., 2014). In addition, SDF-1 participates in muscle regeneration by inducing muscle progenitor/ satellite cell differentiation via both CXCR4 and CXCR7 signaling (Melechionna et al., 2010). In mice, shortly after transplantation, CXCR4 expression by muscle progenitor cells increases their extravasation into skeletal muscle (Perez et al., 2009). In zebrafish, the inhibition of SDF-1/CXCR4 signaling by morpholinos, led to a decrease in $M y o D$ and $M y f 5$ expression, and resulted in fast muscle formation (Chong et al., 2007).

The somites on either side of the axial structures impose a metameric pattern on the embryonic body. They contain multipo-

Fig. 2. Overexpression of $S D F-1$ in the somite leads to an increase in PCNA expression. (A,B) SDF-1 electroporated embryo. (C,D) EGFP electroporated embryo. (B,D) transverse sections of the electroporated somite. After electroporation, embryos were reincubated for 1 day. EGFPpositive somites are indicated by a white arrow. PCNA expression was upregulated in the lateral dermomyotome, which was electroporated with pIRES2-EGFP-SDF-1 construct (black arrow in B), when compared with the contralateral side. PCNA expression in the EGFP electroporated dermomyotome (in D) showed no difference to that of the control side. tent progenitor cells for skeleton, connective tissue, smooth and striated muscles as well as endothelial cells (Brand-Saberi and Christ, 2000; Christ et al., 2007; Ben-Yair and Kalcheim, 2008). One important step for cell differentiation is the somite compartmentalization, which is controlled by signals from the notochord, the dorsal neural tube, the lateral plate mesoderm and the ectoderm, resulting in the subdivision of the somite into a ventral and dorsal part (Brand-Saberi and Christ, 2000; Christ et al., 2004). The ventral part develops to the sclerotome which comprises mesenchymal cells. During later stages of development, the sclerotome undergoes a new alignment called "resegmentation", leading to the fusion of the caudal half of one sclerotome with the cranial half of the following sclerotome. The residual dorsal part maintains the epithelial structure, forming the dermomyotome (DM), which contributes to skeletal muscles and the dorsal dermis (Scaal and Christ, 2004; Yusuf and Brand-Saberi 2006, 2012). Further somitic derivatives are fibroblasts, smooth muscles, and endothelial cells (Brand-Saberi and Christ, 2000). The myotome is built by the dermomyotomal cells from all four borders which slide ventrally to form a complex of cell sheets (Gros et al., 2004). The cells located within the intermediate and lateral half of the dermomyotome are the precursors of the hypaxial muscles, while in the medial half, precursors of the epaxial (deep back) muscles are found (Christ and Ordahl, 1995; Huang and Christ, 2000). At the interlimb level, the ventral dermomyotome extends as an epithelial sheet into the lateral plate mesoderm and generates the hypaxial muscle of the body wall, such as the intercostal muscles (Christ et al., 1983; Denetclaw et al., 1997). Other hypaxial muscle groups, such as the muscles of the extremity, the diaphragm and tongue, are formed in a different manner to the body wall musculature. Here, the ventral dermomyotome cells leave the epithelial dermomyotome after undergoing an epithelial-mesenchymal transition and migrate to their destinations (Chevallier et al., 1977; Christ et al., 1977; Grim,
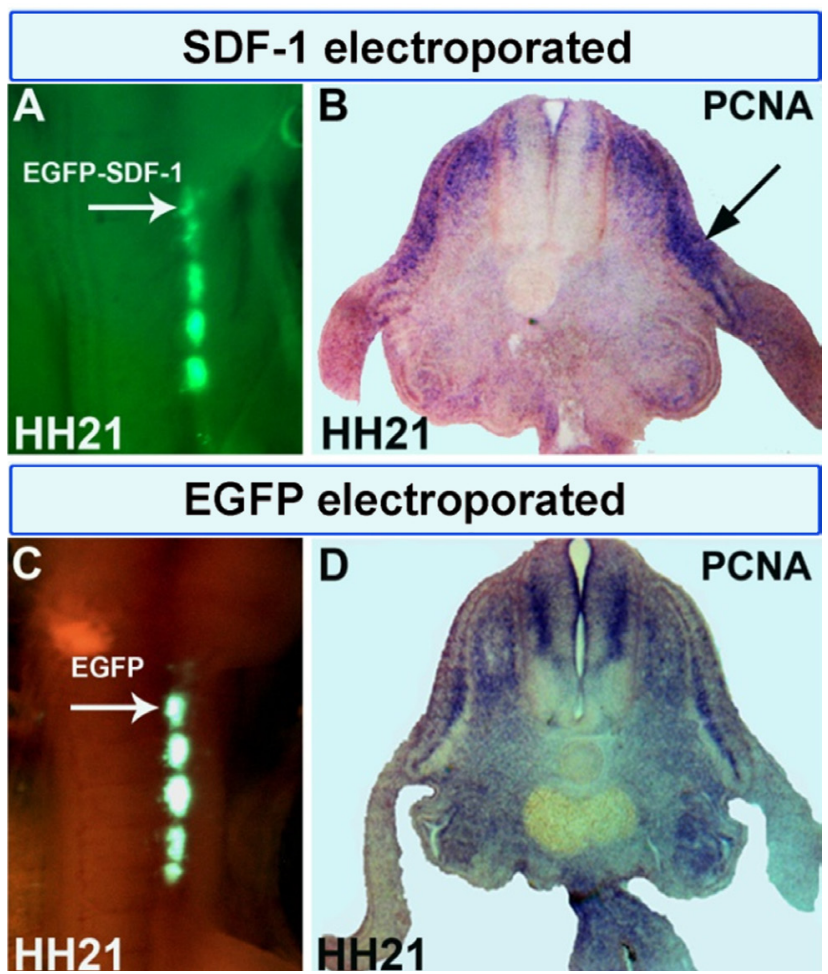
1970; Jacob et al., 1978, 1979; reviewed by Christ and Ordahl, 1995; Vasyutina and Birchmeier, 2006).

Although functions of the SDF-1/CXCR4 axis during skeletal muscle and blood vessel development have been studied, little is known about the role of the SDF-1/CXCR4 axis in the development of the major source of skeletal muscle: the somites that also yield endothelial progenitors. We performed SDF-1-overexpression experiments to gain an insight into the function of the SDF-1/ CXCR4 axis during somite development.

\section{Results}

During development, SDF-1 is expressed in the somites (Rehimi et al., 2008). To investigate the function of SDF-1 in the somites, we performed gain-of-function experiments by means of injecting COS-1-SDF-1-expressing cells and via the electroporation of pIRES2-EGFP-SDF-1 constructs. The operated embryos were analyzed for cell proliferation, skeletal muscle and blood vessel formation.

\section{Over-expression of SDF-1 in the somites leads to an increase in somitic cell proliferation}

To ask whether SDF-1-expression in the somites influences cell proliferation, a pIRES2-EGFP-SDF-1 construct was electroporated into the lateral somite epithelium at Hamburger and Hamiltonstage 15-17 (HH-15-17). After one, and two days of reincubation, the electroporated embryos reached the stage $\mathrm{HH}-21$ and $\mathrm{HH}-24$, respectively. Green fluorescent protein (GFP) could be observed in the lateral parts of the somites located at the interlimb level (Fig. 2A). The operated embryos were fixed and stained via in-situ hybridization using a specific probe for ProliferatingCell-Nuclear-Antigen (PCNA; Köhler et al., 2005). An increase in PCNA-expression was observed in the lateral dermomyotomes
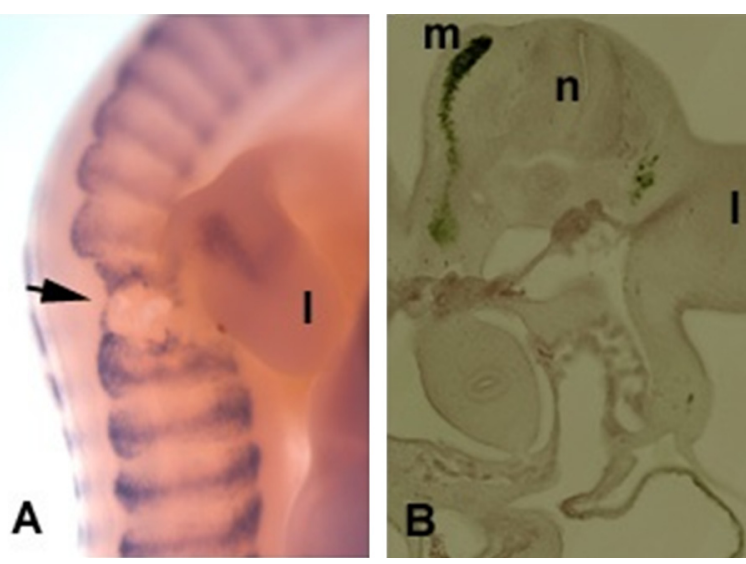

Fig. 4. Implantation of CXCR4 inhibitor beads resulted in a strong reduction of $M y o D$ expression in the somite. (A) MyoD expression in a whole mount chick embryo after the implantation of a CXCR4 inhibitor bead (white small sphere indicated by the arrow) and 2 days of reincubation. MyoD is absent around the implanted beads. (B) Transverse sections of the embryo shown in A at the level of the implanted beads. The MyoD expression can be seen on the left side, while it is almost absent on the right side. Abbreviation: I limb, n neural tube.

in comparison to those on the contralateral side of embryos after one day of reincubation (7 out of 10 cases examined, Fig. 2 B). In the sclerotome, PCNA expression was detected in the dorsal part of both the operated and the unoperated contralateral side. No up-regulation of $P C N A$ was observed in the lateral sclerotome of the operated side. No significant change of PCNA expression can be seen in the dermomyotome in embryos after two days of reincubation ( $n=10$, data not shown). These results demonstrate that SDF-1 enhances cell proliferation selectively in the dermomyotome. However, this proliferation effect of SDF-1 is only observable in the first reincubation day. As a control, an EGFP construct was electroporated into the same region. After one day of reincubation, strong green fluorescence was seen in the lateral somite at the interlimb level (Fig. 2C). PCNA was expressed to the same extent at the electroporated side as on the contralateral side (Fig. 2D). These observations showed that embryos electroporated with the EGFP construct showed no change in PCNA expression in the somites (10 of 10 cases examined).

Fig. 3. SDF-1 overexpression in the lateral somite increases hypaxial myotomal cell number but inhibits the ventrolateral growth of the hypaxial myotome. (A-C) pIRES2-EGFP-SDF-1 electroporated embryo, (D-F) EGFP electroporated embryo. (B,C,E,F) transverse sections of the electroporated somite. After electroporation, embryos were reincubated for a further 2 days. The overexperession of SDF-1 was revealed by EGFP; indicated by arrow in $A, B, D$ and E). MyoD expression domain was wider and shorter in the lateral myotome of the pIRES2-EGFP-SDF-1 electroporated somites (white arrows in C) than that on the contralateral side. (F) MyoD expression on both sides of embryos after electroporation with the EGFP vector was very similar. $L$, limb. 

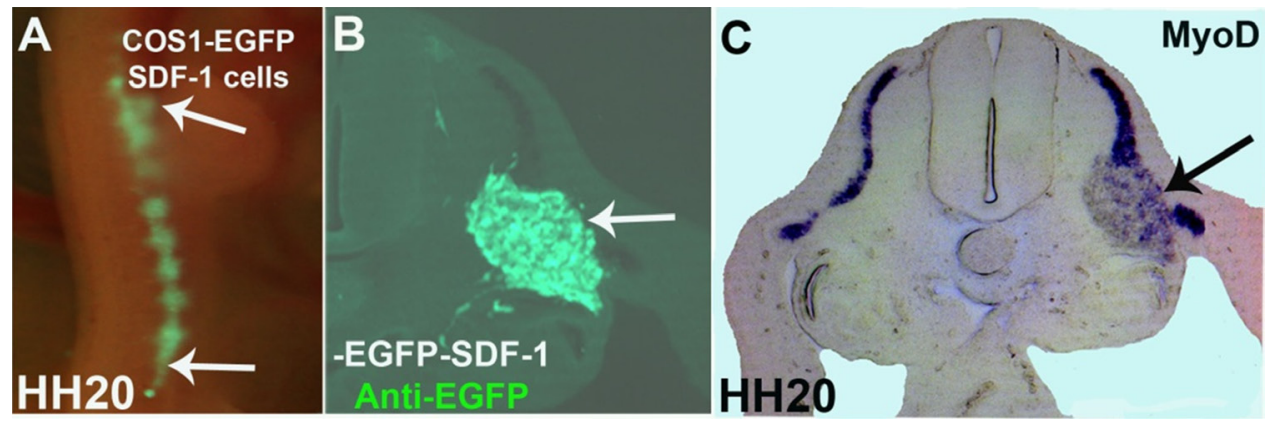

Fig. 5. Injecting SDF-1-expressing cells into somites leads to ectopic localization of myotomal cells. (A-C) COS-1-SDF-1-expressing cells. After injection, embryos were reincubated for 1 or 2 days. MyoD expression was expanded into the sclerotome in which the COS-1-SDF-1-expressing cells were injected (black arrow in C). The SDF-1- expressing cells were revealed by EGFP fluorescence indicated by arrows in $(A, B)$.

\section{Electroporation of the pIRES2-EGFP-SDF-1 construct into the lateral somite increases myotomal cell number}

To determine whether SDF-1-expression in the somite would have an impact on myotome formation, we introduced the pIRES2EGFP-SDF-1 construct into the lateral part of the epithelial somite. An EGFP construct was used in control experiments. After a day of reincubation, the operated embryos were checked in ovo for EGFP expression. Some of the operated embryos were fixed immediately after the examination, while the remaining embryos were allowed to develop for one day more. To assay myotome formation, the embryos were subjected to in situ hybridization with a MyoD probe.

In most of the operated embryos, an EGFP-signal was clearly observed in the lateral somites, especially in the lateral dermomyotome lips (Fig. 3 A,B,D,E). The lateral dermomyotome lip has been reported to be important for the growth of the myotome (Ordahl et al., 2001; Gros et al., 2004; Pu et al., 2013). After one day of reincubation, the $M y o D$ expression in the myotome of the pIRES2EGFP-SDF-1 electroporated somites was very similar to that of the equivalent somites on the contralateral side (data not shown). However, an altered $M y o D$-expression was detected in the embryos after two days of reincubation. In transverse sections through the electroporated somites, SDF-1-expression was revealed by an EGFP-signal in the lateral somites (Fig. 3C). In this region, the $M y o D$ expression domain was significantly wider in comparison to that of the contralateral side ( 8 of 11 cases examined, Fig. 3 $\mathrm{B}, \mathrm{C})$. These results indicate that an enhanced SDF-1-expression in the lateral somites increases the population of myotomal cells in the hypaxial domain.

The $M y o D$ expression pattern in the EGFP electroporated somites did not differ significantly from that of the corresponding somites on the contralateral side. The ventral myotome of the electroporated side extended as far as the myotome on the control side (Fig. 3F). These observations show that electroporation with EGFP alone does not have any effect on $M y o D$ expression in the somite.
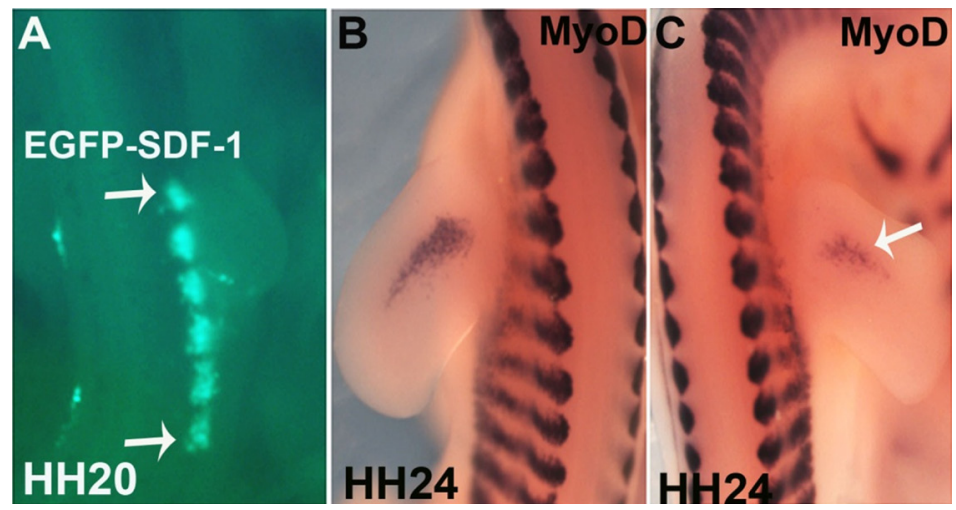

Implantation of CXCR4 inhibitor leads to down-regulation of MyoD expression in the myotome

To test whether the inhibition of SDF-1/CXCR4 signalling had the opposite effect, we analyzed $M y o D$ expression after the implantation of beads soaked with CXCR4 inhibitor. We found that the MyoD expression was significantly down-regulated in the somites where beads had been implanted $(n=8)$. No MyoD expression was seen around the implanted beads (Fig. 4). Our results suggest that SDF-1/ CXCR4 signalling is essential for MyoDexpression in the somites.

\section{Grafting of SDF-1 producing cells into the somites induces ectopic myotomal cells}

To ask whether SDF-1 induces myotomal cell migration, COS1-SDF-1-EGFP-expressing cells were grafted into the somitocoele. After one day of reincubation, we observed EGFP in the somites (Fig. 5A). The operated embryos were fixed after one or two days of reincubation. In transverse sections, $S D F$-1-expressing cells revealed by EGFP were located in the sclerotome (Fig. 5B). The MyoD expression pattern in the myotome was altered (15 out of 18 cases examined, Fig. 5C). MyoD expression extended from the myotome into the domain of the injected SDF-1 cells in the sclerotome. The area of the ectopic MyoD expression was very wide, and extended as far as the injected SDF-1 cells. However, it was less intensive than $M y o D$ expression in the myotome proper. This suggests that myotome cells left their usual position and migrated towards the source of the SDF-1 signal and thus into the sclerotome. As a negative control, embryos injected with COS-1-EGFP-expressing cells showed no change in MyoD expression. These observations indicate that the SDF-1 signal induces myotomal cell migration.

Electroporation of the pIRES2-EGFP-SDF-1 construct into the lateral somites reduces the population of limb muscle cells

It is well known that premyogenic progenitor cells migrate from the lateral dermomyotomes into the limb bud, where they differentiate into muscle cells (Christ and Ordahl, 1995). The migration of a subpopulation of myogenic cells is controlled by the SDF-1/CXCR4 axis (Vasyutina et al., 2005; Yusuf et al., 2006). To reinvestigate the function of SDF-1 on the migration of myogenic precursor cells, SDF-1 was over-expressed in the lateral dermomyotomes by means of electroporating the

Fig. 6. SDF-1 overexpression in the lateral somite decreases hypaxia myotomal cell number in the limb. (A-C) electroporated embryo with pIRES2-EGFP-SDF-1 construct. After electroporation, embryos were reincubated for 2 days. The overexpression of SDF-1 was revealed by EGFP indicated by the arrow in A. MyoD+cell numbers were decreased in the limb of the pIRES2-EGFP-SDF-1 electroporated side (white arrow in $C)$ comparing to those on the contralateral side in (B). 
pIRES2-EGFP-SDF-1 construct into the lateral epithelial somites at the limb bud level. The migration of premyogenic cells starts at stage $\mathrm{HH}-13$, whereas the myogenic differentiation revealed by MyoD expression in the limb bud begins at about $\mathrm{HH}-23-24$. To analyse the limb muscle development, the operated embryos were reincubated for 2 days, reaching $\mathrm{HH}-23-24$. In the whole mount, the $M y o D$-expression was seen in the limb bud on both sides (Fig. $6 \mathrm{~B}, \mathrm{C})$. However, the MyoD-expression in the limb on the operated side was much weaker than those on the contralateral side (Fig. 6 B,C). These observations indicate that the over-expression of $S D F-1$ in the lateral somites stopped the migration of CXCR4-dependent myogenic cells from the somites into limb, and thus led to a reduction of muscle cells in the limb.

In sections of the limb bud, we observed many EGFP-positive cells which migrated from the dermomyotome into the limb bud (Fig. 7 A). Because the limb muscle is significantly reduced after over-expression of SDF-1 in the lateral somite, most of the emigrated somite cells in the limb are unlikely to be myogenic cells. To confirm this hypothesis, co-localization of MyoD and EGFP expression was analysed. We observed that most of EGFP cells were not MyoD positive (Fig. 7 B,C). Only very few EGFP-positive cells overlapped with $M y O D$ expressing cells. This means that most emigrated SDF-1 expressing cells from the somite were not myogenic cells.

\section{Overexpression of SDF-1 in the somite leads to an increase in blood vessel formation in the somite and limb}

Since the somites give rise to not only myogenic, but also to angiogenic cells of the limb (He et al., 2003), most of the non-myogenic somite-derived cells must be angiogenic cells. To analyse the influence of SDF-1 on the blood vessel formation, we first electroporated the pIRES2-EGFP-SDF-1 construct into the lateral portion of the somite. The electroporation was done at $\mathrm{HH} 15-17$. After one to two days of reincubation, the blood vessel formation was analysed using angiogenic gene expression, a quail-specific endothelial cell marker, and ink injection into blood vessels. Because the endothelial marker specifically detects quail endothelia, quail embryos were used for this experimental series.

Fig. 7 (Left). SDF-1 expressing somite cells in the limb were mostly MyoD negative. A shows EGFP-SDF-1 + cells in the limb. (B) MyoD + cells in the limb. Most of the EGFP-SDF-1 + cells in the limb are not co-localized with MyoD+ cells (black arrow in C).

Fig. 8 (Right). Most SDF-1 expressing somite cells differentiate into angiogenic cells in the limb. (A) EGFP-SDF-1 + cells in the limb. (B) VEGFR2 + cells in the limb. EGFP-SDF- $1+$ cells are co-localized with the VEGFR2 + cells (black arrow in C).
To determine whether emigrated SDF-1 expressing cells from the somites into the limb were endothelial cells, the co-expression of EGFP and VEGFR2 was also analysed in sections of the limb. In situ hybridisation with a quail VEGFR2 probe was performed on eight successfully electroporated embryos. Most of the EGFPpositive cells which represented SDF-1 expressing somitic cells resided mostly in the dorsal and ventral parts of the limb, where the VEGFR2-positive cells were located. We observed that many EGFP cells overlapped with VEGFR2 -positive cells (Fig. 8). This indicates that most of the emigrated $S D F-1$ expressing somite cells differentiated mainly into blood vessel endothelial cells in the limb.

Furthermore, we found an increase of VEGFR2+ cells in the somites and limbs (8 out of 11 cases examined, Fig. 9). The increased VEGFR2-positive cells were mainly in the lateral part of the sclerotome and in the limb (Fig. 9B). At the interlimb level, more VEGFR2-positive cells were found in the ventrolateral body wall on the operated side than on the contralateral side (Fig. 9D). The control embryos, which were electroporated with EGFP only, showed no alteration of VEGFR2 expression (data not shown).

An additional five embryos which were successfully electroporated with the pIRES2-EGFP-SDF-1 construct were immunohistochemically stained with a quail endothelial cell marker, the $\mathrm{QH}-1$ antibody $(n=5)$. The number of endothelial cells in the somite and limb on the electroporated side was drastically increased (Fig. 10 $B, D)$. The EGFP electroporated embryos showed no effect on the endothelial cells ( $n=5$, data not shown).

To visualize the vascular network, India ink was injected into the vitelline vessels of electroporated embryos after two days of reincubation $(n=9)$. More blood vessels were formed in the somite region on the
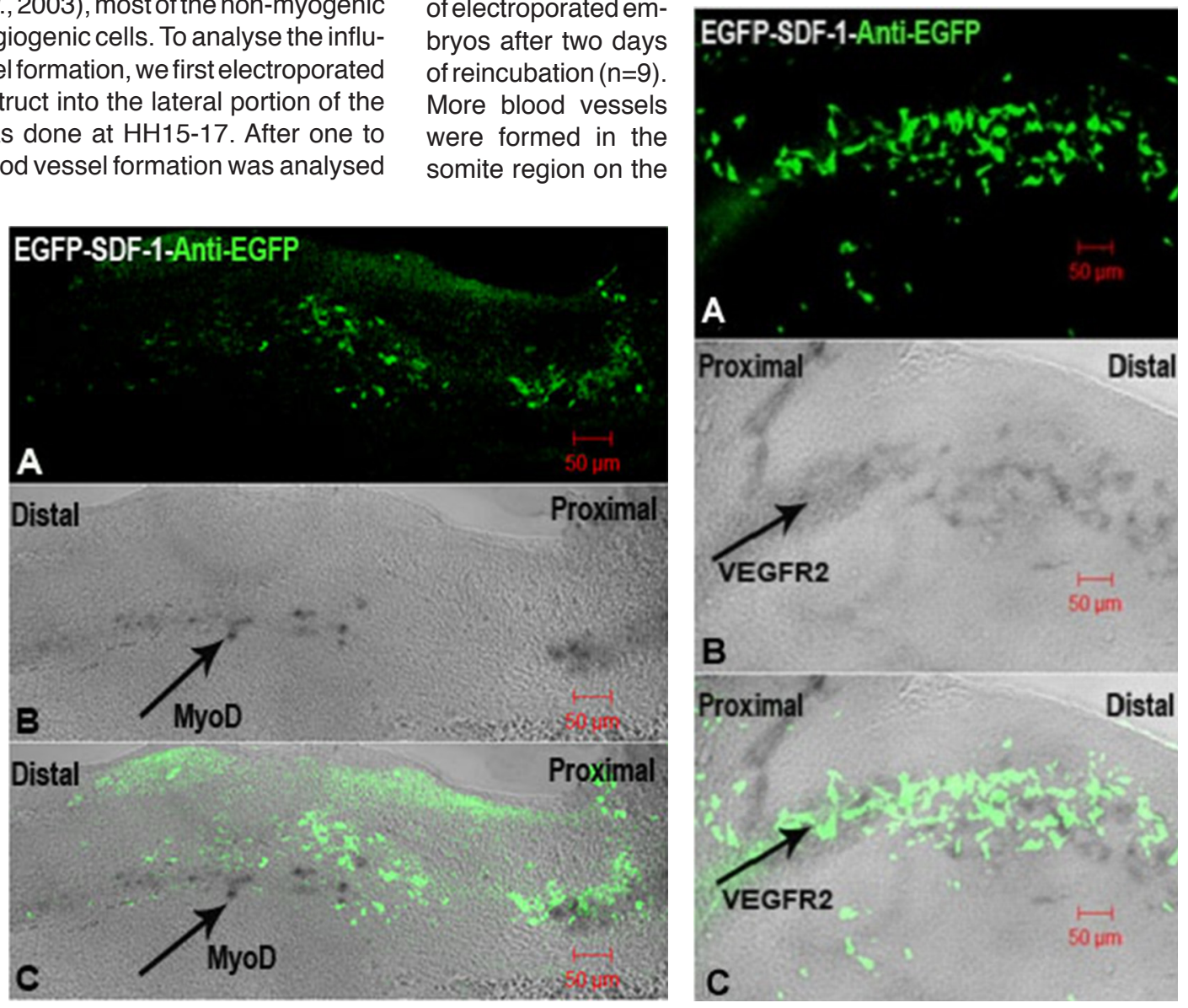
Fig. 9. Overexpression of SDF-1 in somites increases blood vessel endothelial cell number in the somite and the limb. (A-D) pIRES2-EGFP-SDF-1 electroporated embryos. After electroporation, embryos were reincubated for 1 day. The overexpression of SDF-1 was revealed by EGFP (arrows in A, C). VEGFR2 + cell numbers were increased in the somite and the limb of the pIRES2-EGFP-SDF-1 electroporated side (black arrows in $B, D$ ) in comparison to those on the contralateral side (in $B, D$ ).

operated side than on the unmanipulated contralateral side. There were more blood vessels in the limb on the operated side than on the contralateral side too (Fig. 11).

The function of SDF-1 in blood vessel formation was also investigated by means of injecting COS-1-SDF-1-expressing cells into the somitocoele $(n=4)$. Endothelial cells marked with $\mathrm{QH} 1$ were found to be increased in the sclerotome and in the ventrolateral body wall. An agglomeration of $\mathrm{QH}-1$ positive cells was seen around the COS-1-EGFP-SDF-1-expressing cells in the somites (Fig. 12). However, en-
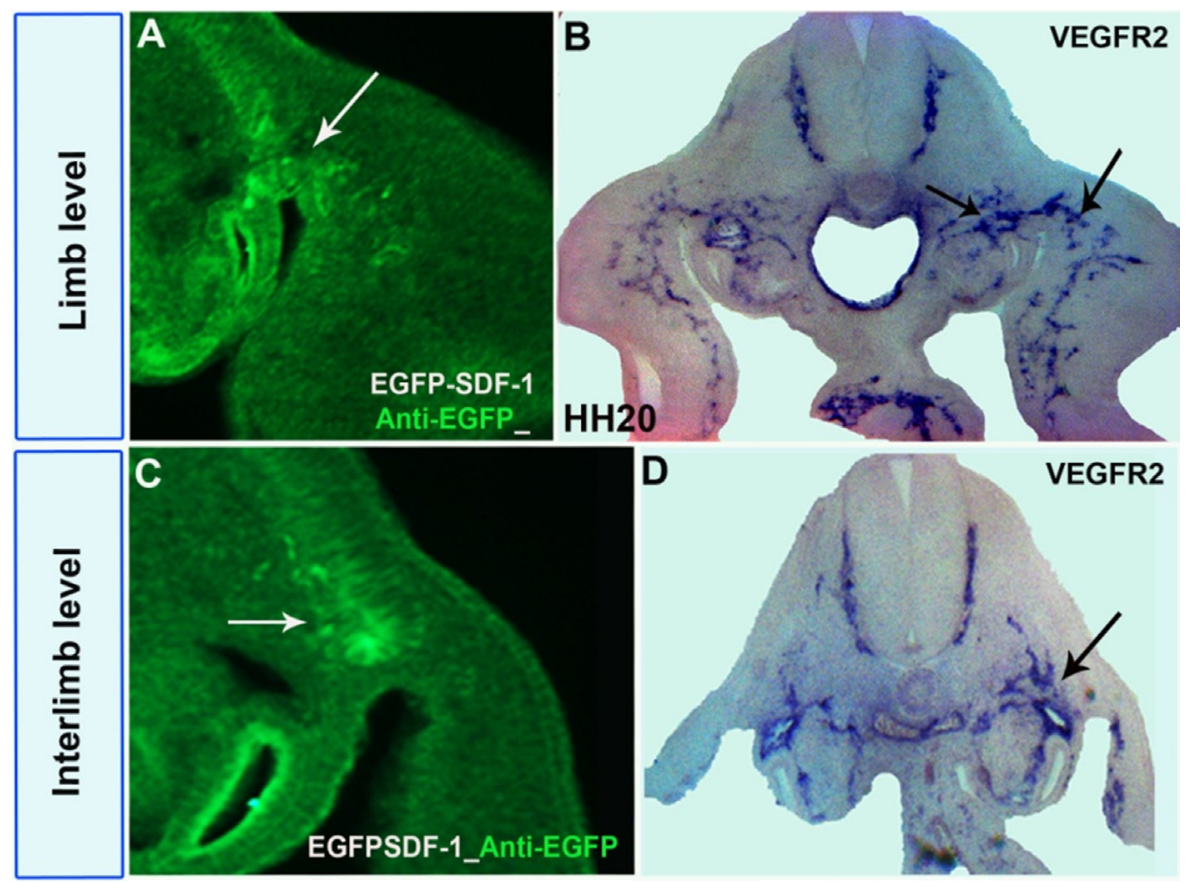

dothelial cells in the limb were not significantly increased. These observations show that SDF-1 cells induce the local production of additional endothelial cells in the somite. The control embryos injected with COS-1-EGFP-expressing cells showed no altered pattern of VEGFR2 and QH-1 (data not shown).

\section{Discussion}

The present study attempted to define the role of SDF-1/CXCR4 during somite development. Our results demonstrate that overexpression of $S D F-1$ in the somites promoted the proliferation of both myogenic and angiogenic progenitors. Moreover, SDF-1 overexpression affected the ventrolateral growth of the myotome and the migration of myogenic precursor cells from somites into the limb.

\section{SDF-1 promotes myotomal and endothelial cell proliferation in the somite}

It has been shown that SDF-1 is involved in the survival of CXCR4-

Fig. 10. Overexpression of SDF-1 increases the endothelial cell number in the lateral part of the dermomyotome and the limb. (A-D) Transverse sections of the somite electroporated with the pIRES2-EGFP-SDF-1 construct. After electroporation, embryos were reincubated for a further day up to HH20. The overexperession of SDF-1 was revealed by EGFP indicated by arrows in $(A, C)$. An increase in endothelial cell number was seen in the somite, limb and ventrolateral body wall; see white arrows in $(B, D)$.
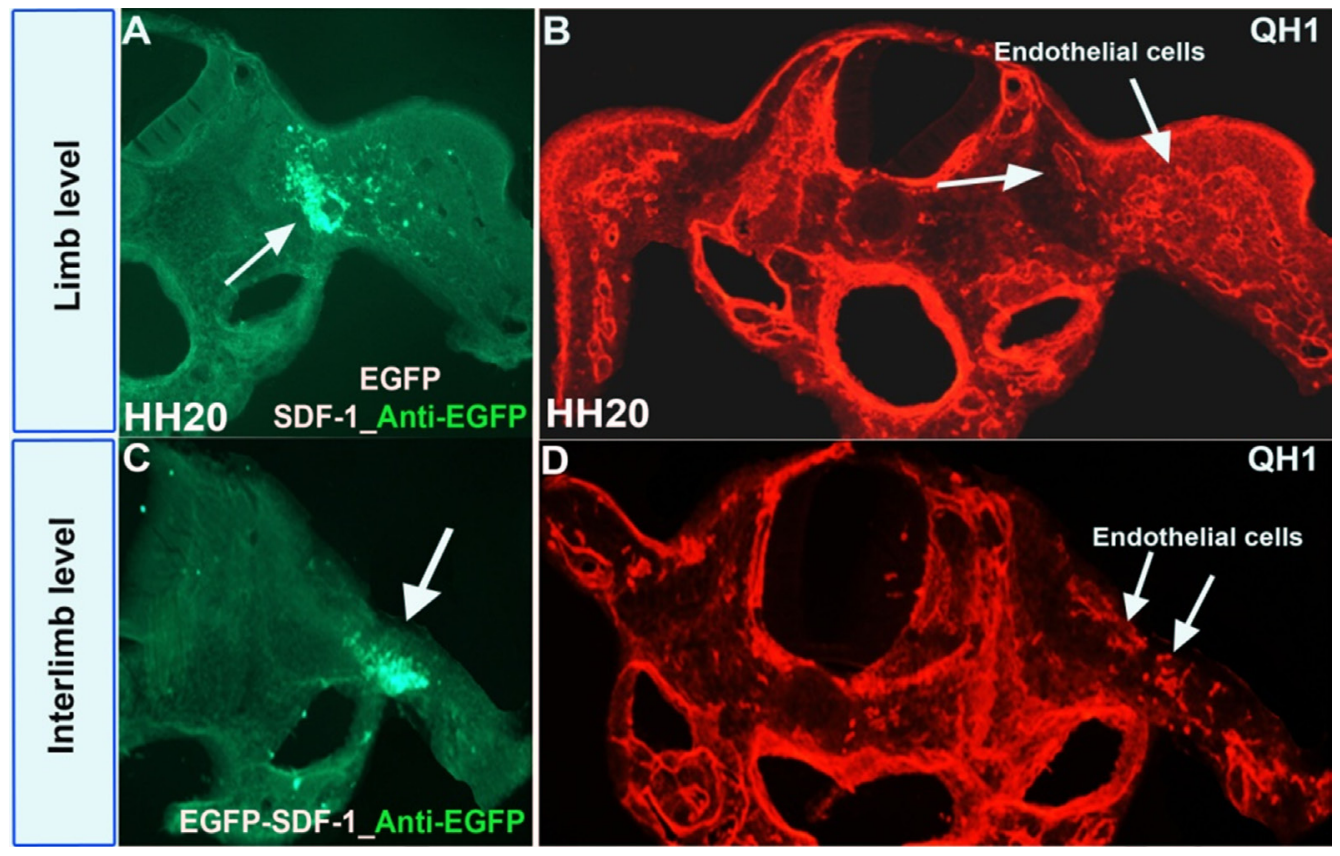
only induced cell proliferation in the somites on the first reincubation day. On the second reincubation day, SDF-1 did not influence the cell proliferation. Such a short term effect of SDF-1 was also reported by other studies (Odemis et al., 2007; Melchionna et al., 2010). After treating C2C12 cells with SDF-1 (10 ng/ml, low concentration) for 24 hours, the number of Ki67-positive (proliferation marker) cells was increased. However, after 48 hours, the number of Ki67-positive cells returned to the same level as under control conditions (Odemis et al., 2007). Treatment of C2C12 myoblasts and mouse satellite cells with SDF-1 (100 ng/ml, high concentration) for 24 hours led to a stimulation of myotube formation. This effect also disappeared after 48 hours of the SDF-1 treatment (Melchionna et al., 2010).

\section{SDF-1 controls myotome formation}

Our results show that overexpression of $S D F-1$ in somites alters myotome formation. First, over-expression of $S D F-1$ by electroporation increased myotomal cell number after 2 days of reincubation. $A$ possible mechanism for this enhanced muscle formation could be the role of SDF-1 in increasing the progenitor pool of somite cells via proliferation during the first day of reincubation. The inhibition of SDF-1/CXCR4 signaling in zebrafish by morpholinos, caused a decrease in fast muscle formation, as well as a decrease in $M y o D$ and Myf5 expression in the somites (Chong et al., 2007). Also in chicken, SDF-1/CXCR4 signaling is required for the myogenic differentiation during myotome formation. This is confirmed by our observation in this study that the MyoD expression was not present in the somites where the beads soaked with CXCR4-inhibitor were implanted.

The second noteworthy finding is that grafting SDF-1-expressing cells into the somites caused an ectopic localization of myotomal cells in the somite. This demonstrates that the SDF-1/CXCR4 axis participates in controlling myogenic cell migration from the dermomyotome into the myotome. However, this signaling pathway is likely to be redundant, because no change in the myotomes was detected in the CXCR4 -/- mutant (Vasyutina et al., 2005). We also observed an intersegmental extension of myotomal cells from one segment to the neighbouring segments. This might be due to the migration of myotomal cells induced by the ectopic location of SDF-1 molecules between somites. Such intersegmental fusion of myotomes can also be observed by over-expressing thymosin beta 15-like peptide in birds (Chankiewitz et al., 2014).

Taken together, the SDF-1/CXCR4 signalling regulates the

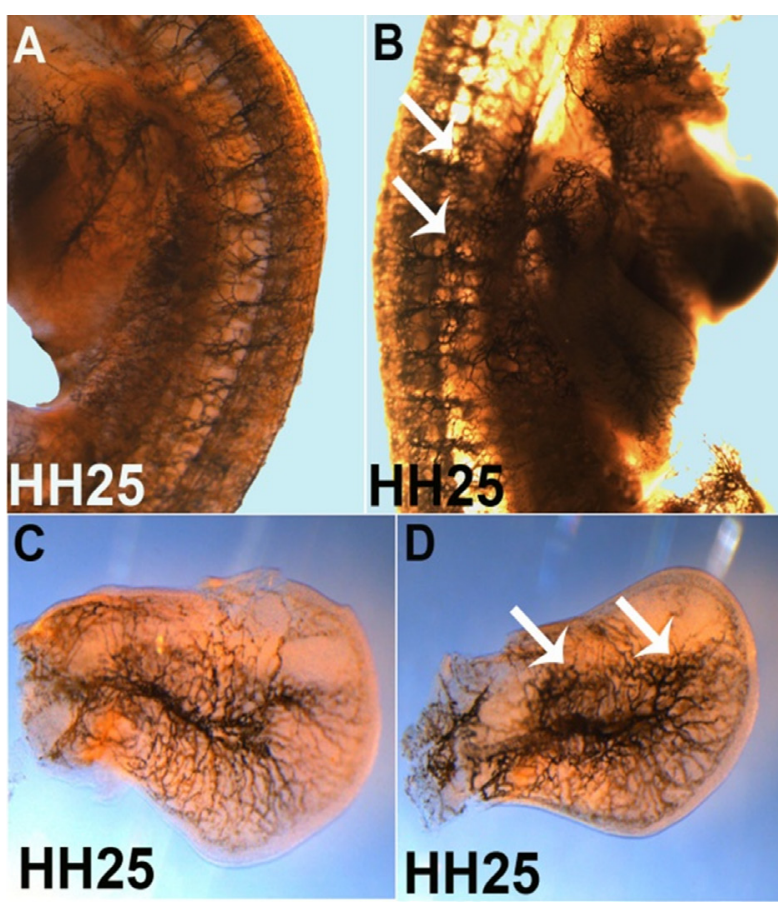

Fig. 11. Overexpression of SDF-1 increases vascularisation in the somite and limb. (A-D) pIRES2-EGFP-SDF-1 electroporated embryo. After electroporation, embryos were reincubated for 2 days up to HH25. In the SDF-1 electroporated side, an increased vascularisation in the somites was observed; see white arrows in (B). Such an increase in vascularisation was also seen in the limb; see white arrows in (D)

myotome formation by means of at least three mechanisms. First, it controls the proliferation of myogenic precursor cells in the dermomyotome; second, it initiates the myogenic differentiation of the myotome cells; finally, it guides the migration of the myotome cells.

\section{SDF-1 controls muscle and blood vessel formation in the limb differently}

It has been shown that the myoblasts, blood vascular endothelial cells and lymphatic endothelial cells of the developing limb are generated from the ventrolateral dermomyotome (He et al., 2003). The cells delaminating from the ventrolateral dermomyotome at limb levels are heterogeneous in terms of their commitment to form muscle and endothelia (Kardon et al., 2002). They exhibit
Fig. 12. Injection of COS-1-SDF-1-EGFPexpressing cells increases endothelial cell number in the somite. (A) Transverse section of the injected somite in a 1 day reincubated quail embryo at $\mathrm{HH} 21$ shows COS-1-secreting SDF-1 cells, indicating by GFP expression; see white arrow in (A). Agglomeration of endothelial cells surrounding the COS-1 secreting SDF-1 cells was observed in the somites; see white arrow in (B).

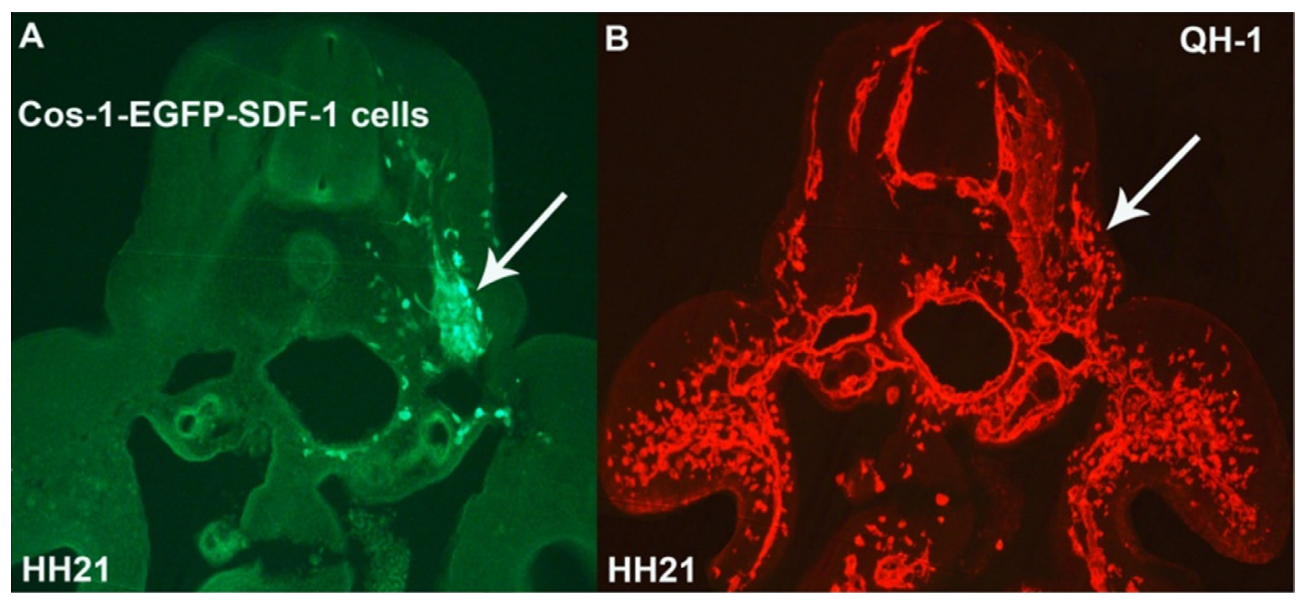


differential traits, indicating that at limb bud levels there is an early fate separation between endothelial and striated muscle lineages (Yvernogeau et al., 2012). We observed a reduction of limb muscle mass after the over-expression of $S D F-1$ in the lateral somite. Simultaneously, limb endothelial cells and blood vessels were increased. Furthermore, most emigrated somite cells in the limb were not myogenic. Most of them were angiogenic cells. These observations indicate that myogenic and angiogenic cell lines are separated before their migration into the limb, as suggested by Yvernogeau et al., (2012). These two cell lines have different responses to the SDF-1 signal. The binding of SDF-1 to CXCR4 in the myogenic cell line activates their migration. A gradient of SDF1 along the proximo-distal axis of the limb controls their directed migration (Vasyutina et al., 2005; Odemis et al., 2005; Yusuf et al., 2006). Augmentation of SDF-1 signal molecules in the somite caused by the experimental overexpression of $S D F-1$ interrupted the SDF-1 gradient in the limb and thus hindered the migration of myogenic cells into the limb.

In contrast, the movement of angiogenic cells seems not to be induced by SDF-1 signals. In spite of overexpression of SDF-1 in the somite, many angiogenic cells could colonize the limb. The colonization of somite-derived angiogenic cells might mainly occur via the sprouting of blood vessels rather than progenitor cell migration found in myogenic progenitor cells. Brand-Saberi et al., (1995) have shown that the vasculature of the avian limb bud is accomplished mainly by the sprouting of vessels. We assume that somite-derived angiogenic progenitor cells differentiate into endothelial cells at the site of their origin and from there they move to the limb via blood vessel sprouting.

In chick and mouse embryos, Tozer et al., (2007) have detected VEGFR2-positive cells in the presumptive wing, and demonstrated that angioblasts colonize the limbs before muscle precursor cells. The vasculogenic capacity of the avascular zone depends on local influences, maybe mediated by the local extracellular matrix (Brand-Saberi et al., 1995). Reversely, ectopic vessels control extracellular matrix production. Moreover, the vasculature organizes itself correctly in the absence of muscles (Tozer et al., 2003). These findings are consistent with our observation that the muscle and blood vessel formation in the limb are differently controlled by the SDF-1/CXCR4 axis.

\section{Conclusion}

Our study demonstrates that SDF-1 promotes the proliferation of both the myogenic, and angiogenic progenitor cells of the somite. SDF-1 also controls the formation of the hypaxial myotome. Moreover, SDF-1 differently controls muscle and blood vessel formation in the limb.

\section{Materials and Methods}

\section{Avian model embryos}

Fertilized chicken and quail eggs were obtained from a local breeder. The eggs were incubated at a temperature of $38^{\circ} \mathrm{C}$ and at $80 \%$ humidity until the required stages. The developing stages were determined according to the staging system of Hamburger and Hamilton (1951).

\section{Preparation of the SDF-1 plasmid}

To construct the SDF-1 plasmid, we performed RT-PCR with a pair of SDF-1 gene-specific primers (sense primer: 5' GCCTGCACCGTCGC-
CAGAATG 3'; and antisense primer:5'AGGCCAACTCCAAACCCATCTTCA $\left.3^{\prime}\right)$. After inserting the RT-PCR product into a pDrive vector, the CSDF-1 insert was verified by sequencing. The complete coding sequence of the cSDF-1 cDNA can be re-harvested from the constructed pDrive- CSDF-1 plasmid following digestion with Nhel and Pstl. To prepare the cSDF-1 plasmid (Fig.1), the Nhel-Pstl fragment including the full-length chicken SDF-1 coding sequence was re-cloned into a prelinearized pIRES2-EGFP vector (BD Biosciences Clontech) which had been handled with the same restriction enzymes. A scrambled DNA sequence was used as a control.

\section{Isolation of SDF-1 plasmid (Maxi preparation)}

Maxi preparation was used to obtain larger volumes of bacterial culture: up to $120 \mathrm{ml}$. The DNA produced from a Maxi preparation can be used for experimental procedures or for probe generation. For the Maxi preparation, a QIAfilterTM Plasmid Maxi Kit was used, provided by the Qiagen Company.

\section{Electroporation technique}

The epithelial dermomyotome of chicken embryos was transfected with the pIRES2-EGFP-SDF-1 construct in the limb and interlimb region. After windowing the egg, the embryo was visualized by injecting $10 \%$ black India ink in a Locke-solution underneath the embryo. During the electroporation, the Locke-solution was added to facilitate manipulation in the embryo. The vitelline and amnionic membranes were removed using Tungsten needles. The manipulation in the embryo was carried out under a dissecting microscope (Leica).

To visualize the DNA plasmid solution, it was mixed with a few crystals of Fast Green powder (Sigma) (Krull, 2004). The DNA-Fast Green solution was sucked into very fine Borosilicate glass capillary $(1.1 \mathrm{~mm}$ internal diameter, Sutter instruments). The glass capillary was then inserted into the epithelial somites at the limb or interlimb levels. The solution was injected using air pressure into the somitocoele. Immediately after the injection, the targeted part of the embryo was electroporated.

Two electrodes were prepared for electroporation, one of platinum as the positive pole and one of tungsten as the negative pole. Uncontrolled spreading of the electric field was prevented by using nail polish on the non-opposing surfaces of the electrodes. Due to its negative charge, the DNA molecule was attracted towards the positive electrode. To target the lateral part of the epithelial somite on the right side, the positive electrode was placed on the right side of the somite, while the negative one was positioned on the left side of the embryo. The settings of the electroporation machine (Intracel TSS20 Ovodyne electroporator) depend on the stage of the embryos. In our experiments, we used 35 volts, 5 square pulses, 200 $\mathrm{ms}$. After electroporation, eggs were re-incubated. After four hours reincubation, EGFP expression could be detected under a dissecting fluorescent microscope (MZFLIII, Leica) with an EGFP filter.

\section{Bead implantation}

The implantation of beads containing the chemical CXCR4 inhibitor T140 was carried out as described in our previous study (Yusuf et al., 2006). Briefly, beads were first prepared by soaking them in T140 solution at a concentration of $10 \mathrm{mg} / \mathrm{ml}$ over-night. Then, a bead was inserted into the somite of a 2-day old chicken embryo. PBS beads were used as controls. The embryos were then reincubated for one to two days.

\section{Cell culture methods}

COS-1 cells were transduced with the SDF-1-EGFP construct (Vasyutina et al., 2005; Rehimi et al., 2010). The cells were grown in a $37^{\circ} \mathrm{C}$ humidified atmosphere of $5 \% \mathrm{CO}_{2}$ in the air. The growth media consisted of Dulbecco's modified Eagle's medium (DMEM; Invitrogen, USA), to which $10 \%$ fetal calf serum (FCS; Invitrogen) and $1 \%$ penicillin.

\section{Whole-mount in-situ hybridization}

Selected embryos were tested for CXCR4, Lbx1, Pax3, MyoD, VEGFR2 and $P C N A$ using specific avian RNA probes. Riboprobes were labeled with a digoxigenin RNA labeling kit from Boehringer, Mannheim, Germany. 
Whole mount in- situ hybridization was performed as described previously (Nieto et al., 1996).

\section{Immunohistochemistry (IHC) on vibratome sections}

Quail and chicken embryos which had been electroporated with pIRES2EGFP-SDF-1 and reincubated up to required stages were fixed in 4\% PFA/ PBT at $4{ }^{\circ} \mathrm{C}$ overnight. Embryos were then embedded in $4 \%$ agarose. The sectioning was done with a vibratome machine at a thickness of $50 \mu \mathrm{m}$. Nonspecific antibody binding was blocked with $1 \%$ bovine serum albumin (BSA) in PBS for 30 min. The sections were incubated with a quail-endothelial cell-specific antibody (QH-1) (1:20), and an anti-EGFP-antibody (Acris, $1: 200)$ as primary antibodies overnight at $4^{\circ} \mathrm{C}$. A Cy3 and Cy2 fluorescent secondary antibody (1:100 in PBS) for 90 minutes at room temperature was subsequently used.

\section{Visualization of blood vessels using ink injection}

To visualize the vascular pattern in the somite and in the limb, a diluted Indian ink (1:10 in Locke solution) was injected into the vitelline vessels of $\mathrm{HH} 24-25$ operated embryos. These embryos were then fixed overnight in $100 \%$ ethanol. Finally, these embryos were cleared in methyl salicylate.

\section{Microscopy and imaging}

Samples were analyzed and photographed after in-situ hybridization by using a Leica MZFLIII microscope and a Leica DC 300F digital camera. Sections were analyzed and photographed using an Axioscope 20 (Zeiss) and a Leica DFC320 digital camera.

\section{Acknowledgment}

We thankAjeesh Balakrishnan-Renuka and Daniel Terheyden-Keighley for their help during the preparation of this manuscript. We thank Rana Houmany and Swantje Wulf at the Institute of Anatomy, Ruhr University Bochum for their excellent technical assistance.

\section{References}

AIUTI, A., WEBB, I. J., BLEUL, C., SPRINGER, T. A. and GUTIERREZ-RAMOS, J. C. (1997). The chemokine SDF-1 is a chemoattractant for human CD34+ hematopoietic progenitor cells and provides a new mechanism to explain the mobilization of CD34+ progenitors to peripheral blood. J Exp Med 185: 111-120.

BAJETtO, A., BARBIERI, F., PATTAROZZI, A., DORCARATTO, A., PORCILE, C., RAVETTI, J. L., ZONA, G., SPAZIANTE, R., SCHETTINI, G. and FLORIO, T. (2006). CXCR4 and SDF1 expression in human meningiomas: A proliferative role in tumoral meningothelial cells in vitro. Neuro Oncol 9: 3-11.

BALKWILL, F. (2004). The significance of cancer cell expression of the chemokine receptor CXCR4. Semin Cancer Biol 14: 171-179.

BEN-YAIR, R. and KALCHEIM, C. (2008). Notch and bone morphogenetic protein differentially act on dermomyotome cells to generate endothelium, smooth, and striated muscle. J Cell Biology 180: 607-618.

BLEUL, C. C., SCHULTZE, J. L. and SPRINGER, T. A. (1998). B lymphocyte chemotaxis regulated in association with microanatomic localization, differentiation state, and B cell receptor engagement. J Exp Med 187: 753-762.

BRAND-SABERI, B. and CHRIST, B. (2000). Evolution and Development of Distinct Cell Lineages Derived from Somites. Curr Top Dev Biol 48: 1-42.

BRAND-SABERI, B., SEIFERT, R. GRIM, M. WILTING, J. KÜHLEWEIN, M. and CHRIST, B. (1995). Blood vessel formation in the avian limb bud involves angioblastic and angiotrophic growth Dev. Dyn. 202: 181-194.

BRZOSKA, E., KOWALEWSKA, M., MARKOWSKA-ZAGRAJEK, A., KOWALSKI, K., ARCHACKA, K.,ZIMOWSKA, GRABOWSKA, M. I., CZERWI'NSKA, A. M., CZARNECKA-G'ORA, M., STREMI'NSKA, W., JA'NCZYK-ILACH, K. and CIEMERYCH, M. A. (2012). Sdf-1 (CXCL12) improves skeletal muscle regeneration via the mobilisation of Cxcr4 and CD34 expressing cells. Biol Cell 104: 1-16.

BUTLER, J. M., GUTHRIE, S. M., KOC, M., AFZAL, A., CABALLERO, S., BROOKS, H. L., MAMES, R., N., SEGAL, M. S., GRANT, M. B. and SCOTT, E. W. (2005). SDF-1 is both necessary and sufficient to promote proliferative retinopathy. $J$ Clin Invest 115: 86-93.
CERADINI, D. J., KULKARNI, A. R., CALLAGHAN, M. J., TEPPER, O. M., BASTIDAS, N., KLEINMAN, M. E., CAPLA, J. M., GALIANO, R. D., LEVINE, J. P. and GURTNER, G. C. (2004). Progenitor cell trafficking is regulated by hypoxic gradients through HIF-1 induction of SDF-1. Nat Med 10: 858-864.

CHEVALLIER, A., KIENY, M., MAUGER, A. and SENGEL, P. (1977). Developmental fate of the somitic mesoderm in the chick embryo. In Vertebrate Limb and Somite Morphogenesis Cambridge University Press 421-431.

CHONG, S. W., NGUYET, L. M., JIANG, Y. J., KORZH, V. (2007). The chemokine sdf-1 and its receptor cxcr 4 are required for formation of muscle in zebrafish. BMC Dev Biol 7: 54-54.

CHRIST, B., JACOB, H. J. and JACOB, M. (1977). Experimental analysis of the origin of the wing musculature in avian embryos. Anat Embryol 150: 171-186.

CHRIST, B., JACOB, M. and JACOB, H. J. (1983). On the origin and development of the ventrolateral abdominal muscles in the avian embryo. An experimental and ultrastructural study. Anat Embryol 166: 87-101.

CHRIST, B., HUANG, R. and SCAAL, M. (2004). Formation and differentiation of the avian sclerotome. Anat Embryol (Berl) 208: 333-350.

CHRIST, B., HUANG, R. and SCAAL, M. (2007). Amniote Somite Derivatives. Dev. Dyn. 236: 2382-2396.

CHRIST, B. and ORDAHL, C. P. (1995). Early stages of chick somite development Anat Embryol 191: 381-396.

DOMENGA, V., P., FARDOUX, P., LACOMBE, M., MONET, J., MACIAZEK, L.T., KREBS B., KLONJKOWSKI, E., BERROU, M., MERICSKAY, Z. L., TOURNIER-LASSERVE, E., GRIDLEY, T. and JOUTEL, A. (2004). Notch3 is required for arterial identity and maturation of vascular smooth muscle cells. Genes Dev. 18: 2730-2735.

DUTT, P., WANG, J. F. and GROOPMAN, J. E. (1998). Stromal cell-derived factor-1o and stem cell factor/kit ligand share signaling pathways in hemopoietic progenitors: a potential mechanism for cooperative induction of chemotaxis. J Immunol 161: 3652-3658.

GANJU, R. K., BRUBAKER, S. A., MEYER, J., DUTT, P., YANG, Y., QIN, S., NEWMAN, W. and GROOPMAN, J. E. (1998). The alpha-chemokine, stromal cell-derived factor- $1 \alpha$, binds to the transmembrane G-protein-coupled CXCR-4 receptor and activates multiple signal transduction pathways. J Biol Chem 273: 23169-23175.

GRIM, M. (1970). Differentiation of myoblasts and the relationship between somites and the wing bud of the chick embryo. Z. Anat. Entwickl.-Gesch. 132: 260-271.

GROS, J., SCAAL, M. and MARCELLE, C. (2004). Atwo-step mechanism for myotome formation in chick. Dev Cell 6: 875-82.

HAMBURGER, V. and HAMILTON, H. L. (1951). A series of normal stages in the development of the chick embryo. Dev Dyn 195: 231-72.

HATCH, H., ZHANG, D., JORGENSEN, M. S. and PETERSEN, B. E. (2002). SDF-1/ CXCR-4: A possible mechanism for bone marrow derived hepatic oval cell recruitment to the rat liver. Cloning Stem Cells 4: 339-352.

HATTORI, K., HEISSIG, B. and RAFII, S. (2003). The regulation of hematopoietic stem cell and progenitor mobilization by chemokine SDF-1. Leuk Lymphoma44:575-582.

HE, L., PAPOUTSI, M., HUANG, R., TOMAREV, S. I., CHRIST, B., KURZ, H. and WILTING, J. (2003). Three different fates of cells migrating from somites into the limb bud. Anat Embryol 207: 29-34

HODOHARA, K., FUJII, N., YAMAMOTO, N. and KAUSHANSKY, K. (2000). Stromal cell-derived factor-1 (SDF-1) acts together with thrombopoietin to enhance the development of megakaryocytic progenitor cells (CFU-MK). Blood 95: 769-775.

HUANG, R. and CHRIST, B. (2000). Origin of the epaxial and hypaxial myotome in avian embryos. Anat Embryol 202: 369-374.

JACOB, M., CHRIST, B. and JACOB, H. J. (1978). On the migration of myogenic stem cells into the prospective wing region of chick embryos. A scanning and transmission electron microsopic study. Anat Embryol 153: 179-193.

JACOB, M., CHRIST, B. and JACOB, H. J. (1979). The migration of myogenic stem cells from the somites into the leg region of avian embryos. Anat Embryol 157:291-309.

JOO, E. K., BROXMEYER, H. E., KWON, H. J., KANG, H. B., KIM, J. S., LIM, J. S. CHOE, Y. K., CHOE, I. S., MYUNG, P. K. and LEE, Y. (2004). Enhancement of cell survival by stromal cell-derived factor-1/CXCL12 involves activation of CREB and induction of Mcl-1 and c-Fos in factor-dependent human cell line MO7e. Stem Cells Dev 13: 563-570.

KAYALI, A. G., LOPEZ, A. D., HAO, E., HINTON, A., HAYEK, A. and KING, C. C. (2012). The SDF-1a/CXCR4 axis is required for proliferation and maturation of human fetal pancreatic endocrine progenitor cells. PLOS ONE 7(6), e38721. 
KOEHLER, T., PROELS, F., BRAND-SABERI, B. (2005). PCNA in situ hybridization: a novel and reliable tool for detection of dynamic changes in proliferative activity. Histochem Cell Biol. 2005 Mar;123(3):315-27.

KRULL, C. E. (2004). A Primer on Using in ovo Electroporation to Analyze Gene Function. Dev. Dyn. 229: 433- 439.

KUCIA, M., JANKOWSKI, K., RECA, R., WYSOCZYNSKI, M., BANDURA, L., ALLENDORF, D. J., ZHANG, J., RATAJCZAK, J. and RATAJCZAK, M. Z. (2004). CXCR4-SDF-1 signalling, locomotion, chemotaxis and adhesion. $J$ Mol Histol 35: 233-245.

LAPIDOT, T. and KOLLET, O. (2002). The essential roles of the chemokine SDF-1 and its receptor CXCR4 in human stemcell homingand repopulation of transplanted immune-deficient NOD/SCID and NOD/SCID/B2m (null) mice. Leukemia 16: 1992-2003.

MAJKA, M., JANOWSKA-WIECZOREK, A., RATAJCZAK, J., KOWALSKA, M. A., VILAIRE, G., PAN, Z. K., HONCZARENKO, M., MARQUEZ, L. A., PONCZ, M. and RATAJCZAK, M. Z. (2000). Stromal derived factor-1 and thrombopoietin regulate distinct aspects of human megakaryopoiesis. Blood 96: 4142-4151.

massa, A., CAsagrande, S., Bajetto, A., PORCILE, C., Barbieri, F., THELLUNG, S., ARENA, S., PATTAROZZI, A., GATTI, M., CORSARO, A., ROBELLO, M., SCHETTINI, G. and FLORIO, T. (2006). SDF-1 controls pituitary cell proliferation through the activation of ERK $1 / 2$ and the $\mathrm{Ca} 2+$-dependent, cytosolic tyrosine kinase Pyk2. Ann N Y Acad Sci 1090: 385-98.

MASYUK M, ABDUELMULA A, MOROSAN-PUOPOLO G, ÖDEMIS V, REHIMI R, KHALIDAN, YUSUF F, ENGELE J, TAMAMURA H, THEISS C, BRAND-SABERI B. (2014). Retrograde migration of pectoral girdle muscle precursors depends on CXCR4/SDF-1 signaling. Histochem Cell Biol 142: 473-488.

MELCHIONNA, R., DI CARLO, A., DE MORI, R., CAPPUZZELLO, C., BARBERI, L., MUSARO, A., CENCIONI, C., FUJII, N., TAMAMURA, H., CRESCENZI, M., CAPOGROSSI, M. C., NAPOLITANO, M. and GERMANI, A. (2010). Induction of myogenic differentiation by SDF-1 via CXCR4 and CXCR7 receptors. Muscle Nerve 41: 828-835.

MÖHLE, R., BAUTZ, F., RAFII, S., MOORE, M. A., BRUGGER, W. and KANZ, L. (1998). The chemokine receptor CXCR4 is expressed on CD34+ hematopoietic progenitors and leukemic cells and mediates transendothelial migration induced by stromal cell-derived factor-1. Blood 91: 4523-4530.

MURDOCH, C. and FINN, A. (2000). Chemokine receptors and their role in inflammation and infectious diseases. Blood 95: 3032-43.

NIMMAGADDA, S., LOGANATHAN, P. G., WILTING, J., CHRIST, B. and HUANG, R. (2004). Expression pattern of VEGFR-2 (Quek1) during quail development. Anat Embryol (Berl) 208: 219-224.

NIMMAGADDA, S., LOGANATHAN, P. G., HUANG, R., SCAAL, M., SCHMIDT, C. and CHRIST, B. (2005). BMB4 and noggin control embryonic blood vessel formation by antagonistic regulation of VEGFR-2(Quek1) expression. Dev Biol280: 100-110.

ODEMIS, V., LAMP, E., PEZESHKI, G., MOEPPS, B., SCHILLING, K., GIERSCHIK, P., LITTMAN, D. R., ENGELE, J. (2005). Mice deficient in the chemokine receptor CXCR4 exhibit impaired limb innervation and myogenesis. Mol. Cell. Neurosci. 30: 494-505.

ODEMIS, V., BOOSMANN, K., DIETERLEN, M. T. and ENGELE, J. (2007). The chemokine SDF1 controls multiple steps of myogenesis through atypical PKCzeta. J Cell Sci 120: 4050-4059.

ODEMIS, V., BOOSMANN, K., HEINEN, A., KURY, P. and ENGELE, J. (2010). CXCR7 is an active component of SDF-1 signalling in astrocytes and Schwann cells. $J$ Cell Sci 123: 1081-1088.
PELED, A., GRABOVSKY, V., HABLER, L., SANDBANK, J., ARENZANA-SEISDEDOS, F., PETIT, I., BEN-HUR, H., LAPIDOT, T. and ALON, R. (1999). The chemokine SDF-1 stimulates integrin-mediated arrest of CD34+ cells on vascular endothelium under shear flow. J Clin Invest 104: 1199- 1211.

RATAJCZAK, M. Z., ZUBA-SURMA, E., KUCIA, M., RECA, R., WOJAKOWSKI, W. and RATAJCZAK, J. (2006). The pleiotropic effects of the SDF-1-CXCR4 axis in organogenesis, regeneration and tumorigenesis. Leukemia 20: 1915-1924.

REHIMI, R., KHALIDA, N., YUSUF, F., DAI, F., MOROSAN-PUOPOLO, G. and BRAND-SABERI, B. (2008). Stromal-derived factor-1 (SDF-1) expression during early chick development. Int. J. Dev. Biol. 52: 87-92.

SCAAL, M. and CHRIST, B. (2004). Formation and differentiation of the avian dermomyotome. Anat Embryol (Berl.) 208: 411 - 424.

SHAWBER, C.J. and KITAJEWSKI, J. (2004). Notch function in the vasculature: insights from zebrafish, mouse and man. Bioessays 26: 225-234.

STELLOS, K., LANGER, H., DAUB, K., SCHOENBERGER, T., GAUSS, A., GEISLER, T., BIGALKE, B., MUELLER, I., SCHUMM, M., SCHAEFER, I., SEIZER, P., KRAEMER, B. F., SIEGEL-AXEL, D., MAY, A. E., LINDEMANN, S. and GAWAZ, M. (2008). Platelet-Derived Stromal Cell Derived Factor-1 Regulates Adhesion and Promotes Differentiation of Human CD34+ Cells to Endothelial Progenitor Cells. Circulation 117: 206-215.

TACHIBANA, K., HIROTA, S., IIZASA, H., YOSHIDA, H., KAWABATA, K., KATAOKA, Y., KITAMURA, Y., MATSUSHIMA, K., YOSHIDA, N., NISHIKAWA, S., KISHIMOTO, T. and NAGASAWA, T. (1998). The chemokine receptor CXCR4 is essential for vascularization of the gastrointestinal tract. Nature 393: 591-594.

TOZER, S., BONNIN, M. A., RELAIX, F., DISAVINO, S., GARCIAVILLALBA, P., COUMAILLEAU, P. AND DUPREZ, D. (2007). Involvement of vessels and PDGFB in muscle splitting during chick limb development. Development 134, 2579-2591.

VASYUTINA, E., STEBLER, J., BRAND-SABERI, B., SCHULZ, S., RAZ, E. and BIRCHMEIER, C. (2005). CXCR4 and Gab1 cooperate to control the development of migrating muscle progenitor cells. Genes Dev 19: 2187-2198.

VASYUTINA, E. and BIRCHMEIER, C. (2006). The development of migrating muscle precursor cells. Anat Embryol 211: 37-41.

WANG, J. F., LIU, Z. Y. and GROOPMAN, J. E. (1998). The $\beta$-chemokine receptor CXCR4 is expressed on the megakaryocytic lineage from progenitor to platelets and modulates migration and adhesion. Blood 92: 756-764.

WANG, J. F., PARK, I. W. and GROOPMAN, J. E. (2000). Stromal cell-derived factor$1 \alpha$ stimulates tyrosine phosphorylation of multiple focal adhesion proteins and induces migration of hematopoietic progenitor cells: roles of phosphoinositide-3 kinase and protein kinase C. Blood 95: 2505-2513.

WRIGHT, D. E., BOWMAN, E. P., WAGERS, A. J., BUTCHER, E. C. and WEISSMAN, I. L. (2002). Hematopoietic stem cells are uniquely selective in their migratory response to chemokines. J Exp Med 195: 1145-1154

YUSUF, F., REHIMI, R., DAI, F. and BRAND-SABERI, B. (2005). Expression of chemokine receptorCXCR4 during chick embryo development. Anat Embryol (Berl) 210: 35-41.

YUSUF, F., REHIMI, R., MOROSAN-PUOPOLO, G., DAI, F., ZHANG, X. and BRANDSABERI, B. (2006). Inhibitors of CXCR4 affect the migration and fate of CXCR4+ progenitors in the developing limb of chick embryos. Dev Dyn 235: 3007-3015.

YVERNOGEAU, L.AUDA-BOUCHER, G. and FONTAINE-PERUS, J. (2012). Limb bud colonization by somite-derived angioblasts is a crucial step for myoblast emigration. Development 139: 277-287.

ZOU, Y. R., KOTTMANN, A. H., KURODA, M., TANIUCHI, I. and LITTMAN, D. R (1998). Function of the chemokine receptor CXCR4 in haematopoiesis and in cerebellar development. Nature 393: 595-599. 


\section{Further Related Reading, published previously in the Int. J. Dev. Biol.}

Two-Pore Channel 2 activity is required for slow muscle cell-generated Ca2+ signaling during myogenesis in intact zebrafish Jeffrey J. Kelu, Hayley L.H. Chan, Sarah E. Webb, Arthur H.H. Cheng, Margarida Ruas, John Parrington, Antony Galione and Andrew L. Miller Int. J. Dev. Biol. (2015) 59: 313-325

Selective depolarization of transmembrane potential alters muscle patterning and muscle cell localization in Xenopus laevis embryos Maria Lobikin, Jean-François Paré, David L. Kaplan and Michael Levin

Int. J. Dev. Biol. (2015) 59: 303-311

mRNA cycles through hypoxia-induced stress granules in live Drosophila embryonic muscles

Annelies M.A. van der Laan, Alice M.C. van Gemert, Roeland W. Dirks, Jasprina N. Noordermeer, Lee G. Fradkin, Hans J. Tanke and Carolina R. Jost

Int. J. Dev. Biol. (2012) 56: 701-709

Sarcosin (Krp1) in skeletal muscle differentiation: gene expression profiling and knockdown experiments Leonie du Puy, Abdelaziz Beqqali, Helena T.A. van Tol, Jantine Monshouwer-Kloots, Robert Passier, Henk P. Haagsman and Bernard A.J. Roelen

Int. J. Dev. Biol. (2012) 56: 301-309

The role of non-muscle myosin IIA in aggregation and invasion of human MCF-7 breast cancer cells

Lara Derycke, Christophe Stove, Anne-Sophie Vercoutter-Edouart, Olivier De Wever, Laurent Dollé, Nathalie Colpaert, Herman Depypere, Jean-Claude Michalski and Marc Bracke Int. J. Dev. Biol. (2011) 55: 835-840

Cytoskeletal heart-enriched actin-associated protein (CHAP) is expressed in striated and smooth muscle cells in chick and mouse during embryonic and adult stages Willemijn van Eldik, Abdelaziz Beqqali, Jantine Monshouwer-Kloots, Christine Mummery and Robert Passier

Int. J. Dev. Biol. (2011) 55: 649-655

Visualization, characterization and modulation of calcium signaling during the development of slow muscle cells in intact zebrafish embryos

Chris Y. Cheung, Sarah E. Webb, Donald R. Love and Andrew L. Miller

Int. J. Dev. Biol. (2011) 55: 153-174

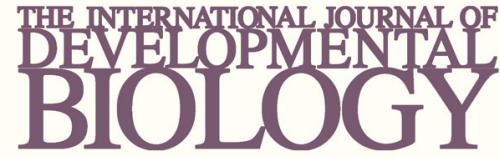

Volume 54 Nos. 6/7
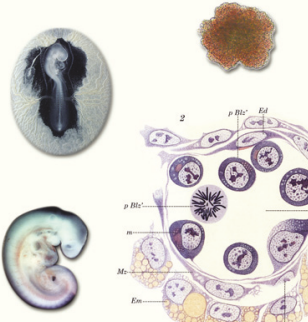

(2)

Special Issue
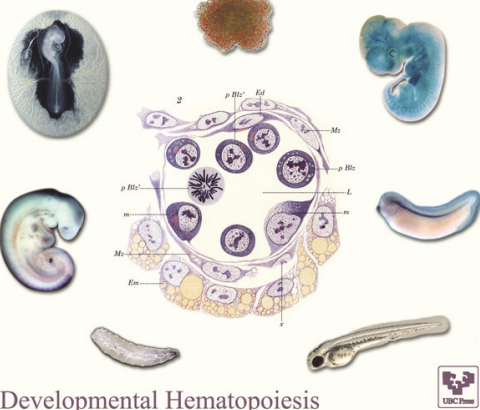

5 yr ISI Impact Factor $(2013)=2.879$

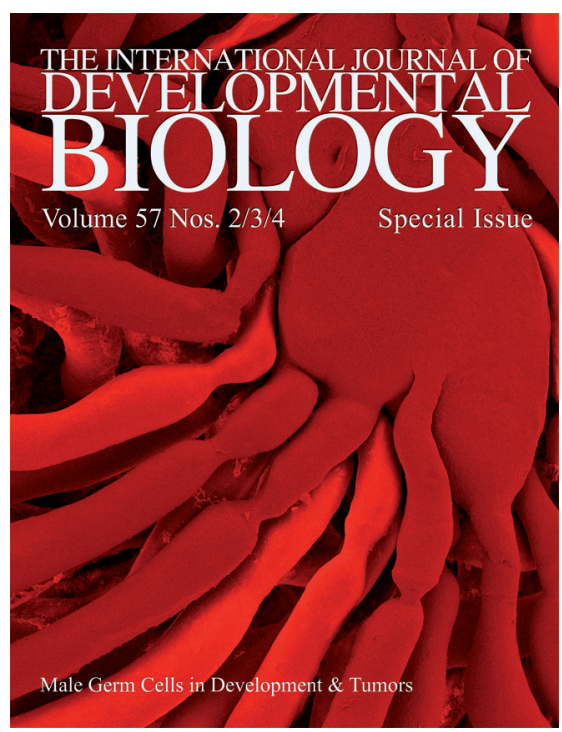

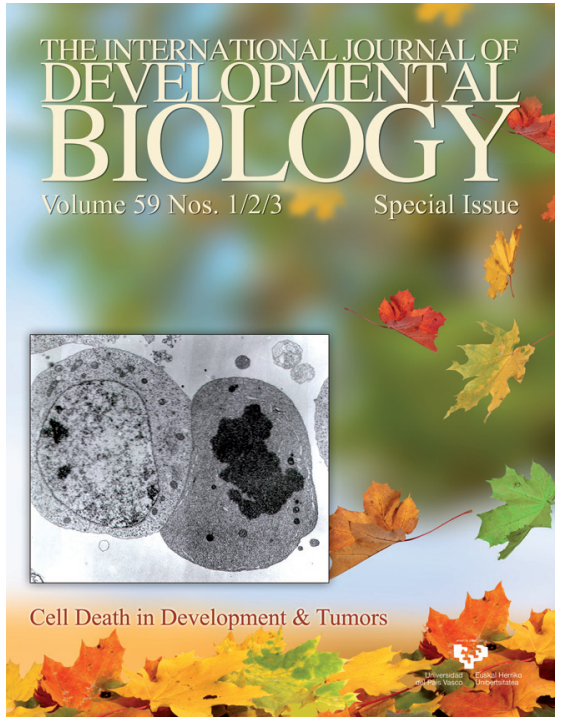

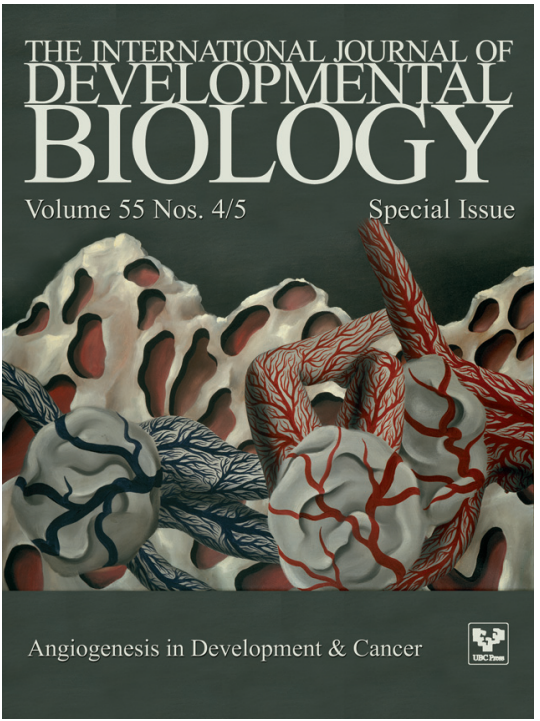

